\title{
COMMERCIAL FRUIT CULTIVATION FOR POVERTY ERADICATE
}

\author{
Chathura Dissanayaka D.M.T.G.C.H. \\ University of Peradeniya, Sri Lanka
}

\begin{abstract}
The objective of the study is examine the how the help fruit village program for eradicate rural poverty. The study conducted under the hypothesis of "Fruit village program very helpful to eradicate all forms of rural poverty". Using mini survey study checked the whether the relationship between poverty eradication of fruit village program. Test the final development outcome of the farmers such as health, infrastructures, education, and livelihood and increase the income of the farmers. Data collected using random sampling method and interviewee farmers and try to use data for develop policy creation based with the final results of the study. The results of the study is very can't believe because of the papaw cultivation are ongoing and farmers are earning money well and they use income for maintain their life very good condition. Actually they live without any poverty highlights. But their method of income book keeping and attitudes of the income are not very satisfied and most of are ideally neutral about satisfaction. And they don't know about separately identified the income, house hold expenses and real profit calculation. Also they have no idea about how to maintain quality of papaw cultivation with appling new technology with post-harvest technology for achieve hi income.
\end{abstract}

Keywords: Fruit Village, Income, Poverty, Food, Agriculture

\section{Introduction}

Poverty is one of major challenge for the development. Most of Asian country depends with agriculture. Every country invests agro base industry, aiming with increase income of farmers and eradicates their poverty. Process of food consumption by the peoples is depending with the food availability of the market. Researchers found, most of noncommunicable deceases coming with lack of fruit consumption by the peoples. The poverty define as a "Condition characterize by server deprivation of basic human need, including food safe drinking water, sanitation, facilities, health, education and information". Sustainable development goals mentions as their challenge, eradicate poverty in all forms and end hunger achieving food security, improve nutrition with promoting sustainable agriculture. Its directly connect with the end poverty among peoples. Our study hypothesis is "fruit village program very helpful to eradicate all form of rural poverty". As a country, "2017 nominate as a year of eradicate poverty by the government. As a practice provincial council of eastern province conducted fruit village program for eradicates the farmer's poverty.

The program already implemented by the department of Agriculture and issued several thousand of plant within farmers and technically supported. Water pump, agro wells and some infrastructures given under half of department contribution. Vulnerable peoples are select as a beneficiary and perform to implement papaw cultivation with compost and bio fertilizer applying. Using mini survey study checked whether the relationship between poverty eradication of fruit village program. Test the final development outcome of the farmer's health, infrastructure, education, livelihood and increase income of the peoples what project objected. Random sampling method will be use collect data. Finally try to check how help this type of program for eradicate poverty and how it's important to development of national economy.

Corresponding Author: Chathura Dissanayaka D.M.T.G.C.H./ chathura.hd@gmail.com

International Conference on Economics and Development 15-16 June 2017, Colombo Sri Lanka 


\section{Objectives}

The main objectives of the study understand the relationship between commercial fruit cultivation under fruit village program and its effect to eradicate poverty. And also another sub objectives are understand the real poverty situation and its indicators, understand the project real output and outcomes, finally how its effect to eradicate rural poverty for achieve national targets.

\section{Methodology}

The study already use primary data and secondary data for the understand research outcome. As a secondary data what use, department of Agriculture extension data and seasonal progress report. And the primary data we collected from the collected commercial papaw cultivators in the Mahaoya, Padiyathalawa and Lahugala area. Generally use the questionnaire and interview method for collect data. And the study is very specially focused in that area between fist 40 beneficiary 10 farmers is randomly selected. The research use framework analyzes method. So we use prioritize questions we try to identifying issues and within small timeframe. The questionnaire address the land ownership, investment to the papaw project, year by year expenditure, income of the project, expenditure food which they are consuming, expenditure to education, infrastructure, other livelihood some of challenge facing by the peoples and peoples satisfaction about the develop impact of papaw project etc.

\section{Literature review}

The study focus about reduce rural poverty in the sector in the Sri Lanka; Poverty is absolutely saying as an income less than us $\$ 2$ per day. Poverty all aviation policy implemented by the every governments involves the strategic use of tool such as education, economic development, health and income redistribution, to improve the livelihood of the world poorest by government and local level to achieve gaols of poverty eradicate internationally. The sustainable development goals already aiming to reduce poverty every way. The consequence of poverty exists on a relative scale. Poverty alleviation is a progress done by lots of government NGO organization within last decades. Its aiming to empower peoples with quality education, health food and water, provision and skills and training, income re distribution, are mainly focus area for that. It wants to take long to see real improvement in the living condition of the community. "The report of poverty and human development in Sri Lanka" Say maternal mortality and child malnutrition in Sri Lanka is very high. Especially in the rural, urban, and estates sector also. It's very hi relate to the poverty. The estate sector has inequality. It's driven by uneven access to infrastructure and education with educational deference's. House hold, labour and demographic ethnicity problems also reason for those inequality situation. The report especially mention about poverty is highly effected to the poor performance in agriculture. Its unintended fallout of government intervention for protects rural sector research. Accessing funding scheme for agriculture their also has a problem. And it's found the system of agriculture investment is wary week also its quality of output also become a very low. The paper of "Strategies and programs for reducing rural poverty in Sri Lanka" Saied some of poverty reducing process, such as Samurdhi programme, self employment progress for the youth, on another poverty eradicate focus programme implemented, and discuss with this programme and also discuss special emerging issue challenge and future direction with the poverty alleviation programme. The study generally guides some 
ideas for government and private sector intervention is very important to poverty alleviation. Finally our some policy creates big problems for the nutrition, health and other lots of sectors.

"The poverty reduction strategy in Sri Lanka" paper tries to understand private and civil society participation for the poverty reduce programme. Its use results oriented method and identifying multidimensional nature of poverty. The research try to reach out poverty situation, a micro economic framework, public action plane, resource plane, structural policy, creating equity, government and public sector management, indicators and a monitoring mechanism. Sri Lanka always receives more donors from the International Monitoring Fund and World Bank under the Regaining Sri Lanka study (2003) issues for poverty Sri Lanka and how addresses the problem.

01. Increase two million new jobs

02. Overcoming public debt crisis.

03. Allocation resource to construct North and East

04. Increasing income level trough increasing productivity and invest.

Finally the report highly recommended good monitoring method. The report of International Fund for Agriculture Development (2012) already highlighted the important of Agro Business for food security and poverty reduction. Generally in third world country farmers product yields are very low and it's create marketable surplus due to access lack of modern technology information \& produce factor. Lack of infra structure facility for access market. Farmers facing missing linkage between farm level production and downstream activity such as processing and marketing. Finally research recommend upgrade entire value chain, straight value technology, proving innovations, sources of financing, stimulating private sector participation, focus area development under local government etc. "The Indonesian rural poverty reduction programme using Agriculture development" discuss about measure it using the fallowing equation,

$$
\mathrm{dP}=\alpha+\varepsilon \beta+\mathrm{y}
$$

The study compare the agriculture, industry and rural service sector contribution for the reduce rural poverty results say only can 12 to 13 percent Agriculture contribution other sector more higher than that so its recommend policy creation for other sectors.

The rural poverty is already we have and we have some of nutrition problems specially vitamin deficiencies anaemia etc. (UNICEF nutrition report 2012) and we have no plans to import fruit and its very hi price so cant access all peoples. Finally we want national fruit demand plane and apply technology for achieve targets. Those all things already mention in the Sustainable development agreement and its dividing to all departments as targets also those are implementing in policy level now. 


\section{Findings}

The special area we covered and understanding the real situation we can seen this type of business commercial projects doing by the farmers. Most of farmer's income generate by their own traditional farming practice. The selected farmers are also doing their papaw cultivation using family workforce specially 1 Ac to 5Ac they maintain by own labor. But some are have two income such as government job and own small business so they have deferent income. And large level cultivators pay their payment to the Mahaveli authority and some are for land owners.

\begin{tabular}{|l|l|l|l|}
\hline & Category & Small scale(01 ac to 05 (1ac to 5ac) & $\begin{array}{l}\text { Large scale } \\
\text { (5ac - to up) }\end{array}$ \\
\hline 01 & Land ownership & Own & $\begin{array}{l}\text { Private, Mahaveli } \\
\text { Government }\end{array}$ \\
\hline 02 & Investment & Own & Company or privet \\
\hline 03 & Zero year invest & Rs.100,000 & Up to Rs.100,000 \\
\hline 04 & Average annual production & $12000 \mathrm{Kg}$ & $12000 \mathrm{Kg}$ \\
\hline 05 & $\begin{array}{l}\text { Price for papaw Rs. 30 to 90 } \\
\text { (per one Kg ) Income average }\end{array}$ & Rs.10,80,000 & Rs.10,80,000 \\
\hline 06 & Market & Villagers, mobile and weekly fair & Company, national Market \\
\hline 07 & Annual expenditure & Rs.420,000 & Rs.420,000 \\
\hline 08 & Fertilizer & Compost and chemicals & Compost and chemicals \\
\hline 09 & Monthly net income (Average) & 48000 & 48000 \\
\hline
\end{tabular}

The department of agriculture introduce the program with aiming to the introduce new income, popular organic fruits, and develop framers livelihood but farmers already use chemicals and chemical fertilizers for the field. The all of papaw cultivators have some challenges such as droughts with climate change, insect affected and marketing problems for the product. The larger level expenditure is very high and its income share with government, labors and owners but in small scale they have no land expenditure, laborious are family members as a results they can use those income as their family expenditure, and also given some jobs opportunity for families in the village. The income has some special because the income can generate monthly, but it's depend the good condition in the field. So family income can continue and its develop family infra structure also. The all members of family's normal food consumption they continue it's a mixture of local food and imported foods. After the starting this project they automatically include some more food, fruit and vegetable for their meals specially hi protein are added. This potion helps to increase family nutrition level.

The education expenditure of the family is also good they spend advance level and degree or diploma level education. Most of are traveling to faraway for quality education. The infra structure development such as electricity, water supply, shelter, home garden, and perches agro related vehicle also. Another factor is health cost of the family it's near to Rs. 2000 per month its mean their health situation in good condition it's as a result of family labors. Generally they use their fruits product also villager's fruits consumptions growing with the availability of local fruit products. It's specially use organic manures so it's healthy than other fruits which are in the available markets. But some time they use chemicals and chemical fertilizer to the plants. Problem is no any measurement or guideline to control these types of chemical use. 
Proceeding of the International conference on Economic and Development, Vol. 1, 2017, pp. 1-6

\section{Results and discussion}

We identified the papaw plant is a very sensitive plant for the drought and climate change. It's mainly effect to the production some time production totally fails. Some bacteria affection and white dots (biliea bugs) highly attracted those are biological challenge for the papaw cultivation. Another challenge is local and national market failure directly effect to the papaw cultivation and its price variation only festival time reported hi price for fruits.

Hi temperature and long rainfall can effect to the pollination it's directly effect to the production. The farmers are not aware about rite use of chemical and use of post harvest techniques. And the government of Sri Lanka has no quality checking method for local food those problems are reason to didn't control the chemical usage for food. Also farmers are aware about something of technology can implement. Also laborers are not aware about quality control, equipment use and post harvest technology also. The large scale farmers have some linkage with the company in the starting level but the privet company only purchases product under hi quality. Without hi quality they want to supply product for local market and its has competition again.

The farmers are requesting government intervention for the continue good price and market channel for continue income. And as a post harvesting method they use news paper for cover fruit. Some time reported used ethylene for the fruits those are practical problems we should give to solution.

As a project we can see papaw cultivation is a good solution for eradicate poverty NPV calculation (Table 01) show the results. The results show the below positive price mean the project is very successful.

\begin{tabular}{|l|r|r|r|r|}
\hline \multicolumn{5}{|c|}{ Net present value calculation } \\
\hline Year & 0 & 1 & 2 & 3 \\
\hline Expenditure & -200000 & 420000 & 420000 & 420000 \\
\hline Income & 0 & 800000 & 900000 & 1000000 \\
\hline Net income & -200000 & 380000 & 480000 & 580000 \\
\hline Rate & $13 \%$ & & & \\
\hline NPV & $\mathbf{\$ 8 0 8 , 9 9 3 . 5 3}$ & & & \\
\hline
\end{tabular}

\section{Conclusion}

The aim of the study is identifying a good solution for the eradicate rural poverty using local sources the programme implemented by the department of Agriculture and the other NGO and INGO for address this issue. Technically and theoretically the programme are very satisfied success full but the real situation is farmer's attitude about the papaw cultivation its half of farmers are satisfied another half are neutral about the satisfaction. The reason is their income and expenditure are mixed with the domestic expenditure and they spend time year around as a labour in the field but monthly income is near to Rs.50, 000 so they compare it with paddy and other seasonal crops. But papaw is a good nutrition with should increase available in the market and also quality of product directly effect to the price of the papaw and year around cultivation control by the weather condition. And labour cost is 
very high finally we can understand the real situation they think to save more money after their expenditure. So they have some neutral idea about income. But as a solution for eradicate poverty its good solution government should plan annual production within across country its help to continue best price for product. Another problem is quality of product it's should aware people and train farmers for continue quality with organic condition and if we can popular organic product within people its good solution for price. Also we can introduce by-products for the papaw. Finally the papaw production is a commercially good solution for eradicate rural poverty.

\section{References}

Lacey A. and Luff D. Qualitative Research Analysis. The NIHR RDS for the East Midlands / Yorkshire \& the Humber, 2007.

Gunnathilaka R, Won.G, Chatterjee.S, (2009) "Poverty and human development in the Sri Lanka." Asian development Bank.

Dr.Thennakoon. D, (2003) “Stratagies and programe for redusing rural poverty in Sri Lanka." Economic reviewe P.no. 22-26.

Jefferjee A and Senanayaka D, (2004) “Poverty reduction Strategy in Sri Lanka” Briefing paper series no 3 , Center for poverty analyze.

Suryahadi A, Hadiwijaja G, (2011) "The role of Agriculture in poverty reduction in Indonesia" Jakartha Indonisia, SMURU Research institute pa.No - 16-20.

Department of Agriculture Seasonal Report 2016/2017 